\title{
Systemic Treatments for Lung Cancer Patients Receiving Hemodialysis
}

\author{
TZEWAH V. LEUNG, PharmD, BCOP, MITCHELL E. HUGHES, PharmD, BCPS, BCOP, \\ CHRISTINE G. CAMBARERI, PharmD, BCPS, BCOP, DANIEL J. RUBIN, PharmD, and \\ BETH EABY-SANDY, MSN, CRNP, OCN ${ }^{\circledR}$
}

From Abramson Cancer Center, Hospital of the University of Pennsylvania, Philadelphia, Pennsylvania

Authors' disclosures of conflicts of interest are found at the end of this article.

Correspondence to: Tzewah V. Leung, PharmD, BCOP, 3400 Civic Center Blvd, West Pavilion, 4th Floor Pharmacy, Philadelphia, PA 19104. E-mail: vivian.leung@uphs.upenn.edu https://doi.org/10.6004/jadpro.2018.9.6.4 (c) 2018 Harborside $^{\text {TM }}$
J Adv Pract Oncol 2018:9(6):614-629

\begin{abstract}
Chemotherapy, and now targeted therapies and immunotherapies, are widely used for the management of patients with all stages of lung cancer. Some challenges present when patients are receiving concomitant hemodialysis for various comorbid conditions. However, this should not immediately rule out a patient for treatment. Many drugs may be safely given to patients who are receiving hemodialysis with the proper dosing schedule and careful monitoring. This article will outline the current literature surrounding the use of these drugs in patients undergoing active hemodialysis while being treated for lung cancer.
\end{abstract}

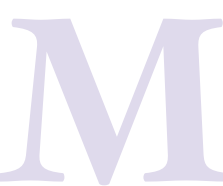

etastatic lung cancer is the leading cause of cancer death in the United States. These patients often have several comorbidities given their risk factors for developing lung cancer. Managing lung cancer patients with severe renal impairment or end-stage renal disease requiring hemodialysis (HD) remains a significant clinical challenge. Chemotherapy, immunotherapy, and targeted therapy can at times be given as treatment with careful consideration of pharmacokinetics and pharmacodynamics properties.

\section{CHEMOTHERAPY \\ Platinum Drugs}

Platinum drugs make up the cornerstone of many solid tumor chemo- therapy regimens (Table 1). These agents crosslink strands of DNA, leading to antimitotic effects from the inability of DNA to be repaired and further replicated. Appropriate dosing of platinum agents is critical as these drugs can cause numerous adverse effects. Multiple case studies exist pertaining to the effect of $\mathrm{HD}$ on cisplatin and carboplatin in lung cancer.

Cisplatin: Cisplatin is eliminated primarily by the kidneys (BristolMyers Squibb, 2010a). Administering cisplatin in $\mathrm{HD}$ patients requires dose adjustments in order to prevent toxicities associated with cisplatin separate from the nephrotoxicity. Also, timing of the cisplatin with HD must be considered. Since patients are already on HD, nephrotoxicity is not the major concern and intrave- 


\begin{tabular}{|c|c|c|c|}
\hline Medication & Indication & Dose & Pharmacodynamics \\
\hline Cisplatin & $\begin{array}{l}\text { - NSCLC } \\
\text { - SCLC limited } \\
\text { and extensive } \\
\text { stage }\end{array}$ & $\begin{array}{l}\text { - NSCLC: } 75-100 \mathrm{mg} / \mathrm{m}^{2} \\
\text { - SCLC limited stage: } 60 \mathrm{mg} / \mathrm{m}^{2} \text {; } \\
\text { SCLC extensive stage: } \\
80 \mathrm{mg} / \mathrm{m}^{2}\end{array}$ & $\begin{array}{l}\text { - Metabolism: inactivated by sulfhydryl groups } \\
\text { in the bloodstream and cells } \\
\text { - Excretion: urine (>90\%); feces (minimal) }\end{array}$ \\
\hline Carboplatin & $\begin{array}{l}\text { - NSCLC } \\
\text { - SCLC }\end{array}$ & $\begin{array}{l}\text { - NSCLC: AUC 2-6 } \\
\text { - SCLC: AUC 5-6 }\end{array}$ & $\begin{array}{l}\text { - Metabolism: hepatic (minimal) to aquated } \\
\text { and hydroxylated compounds } \\
\text { - Excretion: urine ( } 70 \% \text { as carboplatin; } 3 \%-5 \% \\
\text { as platinum) }\end{array}$ \\
\hline Docetaxel & $\begin{array}{l}- \text { NSCLC } \\
\text { - SCLC }\end{array}$ & $\begin{array}{l}\text { - NSCLC: } 75-100 \mathrm{mg} / \mathrm{m}^{2} \\
\text { - SCLC: } 100 \mathrm{mg} / \mathrm{m}^{2}\end{array}$ & $\begin{array}{l}\text { - Metabolism: hepatic via oxidation by CYP3A4 } \\
\text { - Excretion: feces ( } 75 \%) \text {; urine }(\sim 6 \%)\end{array}$ \\
\hline Etoposide & $\begin{array}{l}\text { - NSCLC } \\
\text { - SCLC }\end{array}$ & $\begin{array}{l}\text { - NSCLC: } 50-100 \mathrm{mg} / \mathrm{m}^{2} \\
\text { - SCLC: IV } 35-120 \mathrm{mg} / \mathrm{m}^{2} \\
\text { po } 100-200 \mathrm{mg} / \mathrm{m}^{2} / \text { day }\end{array}$ & $\begin{array}{l}\text { - Metabolism: hepatic via CYP3A4 and 3A5, } \\
\text { prostaglandin synthases, glutathione, and } \\
\text { glucuronide conjugation } \\
\text { - Excretion: urine ( } 56 \%) \text {; feces (44\%) }\end{array}$ \\
\hline Gemcitabine & $\begin{array}{l}\text { - NSCLC } \\
\text { - SCLC }\end{array}$ & $\begin{array}{l}\text { - NSCLC: } 1,000-1,250 \mathrm{mg} / \mathrm{m}^{2} \\
\text { - SCLC: } 1000-1250 \mathrm{mg} / \mathrm{m}^{2}\end{array}$ & $\begin{array}{l}\text { - Metabolism: metabolized intracellularly by } \\
\text { nucleoside kinases to the active diphosphate } \\
\text { and triphosphate nucleoside metabolites } \\
\text { - Excretion: urine (inactive metabolite } 92 \% \text { - } \\
\text { 98\%); feces }(<1 \%)\end{array}$ \\
\hline Irinotecan & $\begin{array}{l}\text { - NSCLC } \\
\text { - SCLC }\end{array}$ & $\begin{array}{l}\text { - NSCLC: } 60 \mathrm{mg} / \mathrm{m}^{2} \\
\text { - SCLC: } 60-175 \mathrm{mg} / \mathrm{m}^{2}\end{array}$ & $\begin{array}{l}\text { - Metabolism: primarily hepatic by } \\
\text { carboxylesterase enzymes; may also undergo } \\
\text { CYP3A4 metabolism } \\
\text { - Excretion: urine (>90\%); feces (minimal) }\end{array}$ \\
\hline Paclitaxel & $\begin{array}{l}\text { - NSCLC } \\
\text { - SCLC }\end{array}$ & $\begin{array}{l}\text { - NSCLC: } 135 \mathrm{mg} / \mathrm{m}^{2} \\
\text { - SCLC: } 80-175 \mathrm{mg} / \mathrm{m}^{2}\end{array}$ & $\begin{array}{l}\text { - Metabolism: hepatic via CYP2C8 and 3A4 } \\
\text { - Excretion: feces ( } 71 \%) \text {; urine }(\sim 14 \%)\end{array}$ \\
\hline Nab-paclitaxel & - NSCLC & - NSCLC: 100 mg/m² & $\begin{array}{l}\text { - Metabolism: hepatic via CYP2C8 (major) and } \\
\text { CYP3A4 (minor) } \\
\text { - Excretion: feces (20\%); urine (4\%) }\end{array}$ \\
\hline Pemetrexed & $\begin{array}{l}\text { - NSCLC, } \\
\text { nonsquamous }\end{array}$ & - NSCLC: 500 mg/m² & $\begin{array}{l}\text { - Metabolism: minimal } \\
\text { - Excretion: urine (70\%-90\%) }\end{array}$ \\
\hline Temozolomide & $\begin{array}{l}\text { - NSCLC } \\
\text { - SCLC }\end{array}$ & $\begin{array}{l}\text { - NSCLC: } 75 \mathrm{mg} / \mathrm{m}^{2} / \text { day } \\
\text { - SCLC: } 75 \mathrm{mg} / \mathrm{m}^{2}\end{array}$ & $\begin{array}{l}\text { - Metabolism: hydrolyzed to active MTIC } \\
\text { - Excretion: urine ( } 38 \% \text {; parent drug } 6 \%) \text {; } \\
\text { feces }(<1 \%)\end{array}$ \\
\hline Topotecan & $\begin{array}{l}\text { - } \text { SCLC } \\
\text { relapsed }\end{array}$ & $\begin{array}{l}\text { - SCLC: IV } 1.5 \text { mg } / \mathrm{m}^{2} / \text { day; } \\
\text { po } 2.3 \mathrm{mg} / \mathrm{m}^{2} / \text { day }\end{array}$ & $\begin{array}{l}\text { - Metabolism: pH-dependent hydrolysis } \\
\text { - Excretion: IV: urine (51\%), feces (18\%); } \\
\text { po: urine (20\%), feces }(33 \%)\end{array}$ \\
\hline Vinorelbine & - NSCLC & - NSCLC: $25-30$ mg/m² & $\begin{array}{l}\text { - Metabolism: hepatic via CYP3A4 } \\
\text { - Excretion: feces (46\%); urine (18\%) }\end{array}$ \\
\hline
\end{tabular}

nous (IV) fluids should not be added to the regimen as they routinely are included for non-HD patients. Table 2 summarizes several case studies in the literature evaluating the dosing of cisplatin in end-stage renal disease (ESRD) patients.

There is a general consensus among case studies to reduce the cisplatin dose by $50 \%$; however, the timing of the HD varies. Hemodialysis primarily removes only the free cisplatin. This free cisplatin is generally not replaced by the plasma- bound cisplatin, so administration of the cisplatin can occur following HD or on non-HD days (Janus, Thariat, Boulanger, Deray, \& Launay-Vacher, 2010). Removing the free cisplatin via HD directly after infusion may be counterintuitive as most of the free cisplatin would then be removed, potentially lessening the cytotoxic effect and possible antitumor activity. A case study involving an accidental overdose in a lymphoma patient with 750 $\mathrm{mg}$ of cisplatin showed HD is ineffective in remov- 


\section{Table 2. Chemotherapy Dose Adjustments in Hemodialysis}

\begin{tabular}{|c|c|c|}
\hline Medication & $\begin{array}{l}\text { Package insert } \\
\text { recommendation }\end{array}$ & Literature recommendations \\
\hline Cisplatina & $\begin{array}{l}\text { - PI does not recommend } \\
\text { using in dialysis; } \\
\text { contraindicated }\end{array}$ & $\begin{array}{l}\text { - Administer } 50 \% \text { of dose post hemodialysis } \\
\text { " Partially cleared by } \mathrm{HD} \\
\text { " Doses up to } 80 \mathrm{mg} / \mathrm{m}^{2} \text { tolerated } \\
\text { " Highly and irreversibly bound to plasma proteins } \\
\text { " Free cisplatin is dialyzable; however, loss of free cisplatin } \\
\text { does not affect already bound cisplatin } \\
\text { " Administer } 12-24 \text { hours before } \mathrm{HD} \text { sessions } \\
\text { - Administer } 50 \% \text { of dose if on continuous ambulatory } \\
\text { - peritoneal dialysis } \\
\text { - Administer } 75 \% \text { of dose if on continuous renal replacement } \\
\text { therapy }\end{array}$ \\
\hline Carboplatin ${ }^{b}$ & $\begin{array}{l}\text { - No manufacturer } \\
\text { recommendations for } \\
\mathrm{CrCl} \leq 15 \mathrm{~mL} / \mathrm{min}\end{array}$ & $\begin{array}{l}\text { - Administer } 50 \% \text { of usual dose post hemodialysis } \\
\text { » Dialyzable } \\
\text { "Administer carboplatin after HD session when GFR is } \\
\text { approximately equal to O to enter into the Calvert equation } \\
\text { »Carboplatin is removed by HD; administer on a nondialysis } \\
\text { day and perform HD } 12-24 \text { hours later } \\
\text { - Administer } 25 \% \text { of usual dose on CAPD } \\
\text { - Administer } 200 \mathrm{mg} / \mathrm{m}^{2} \text { on CRRT }\end{array}$ \\
\hline Docetaxelc & $\begin{array}{l}\text { - Renal excretion is minimal } \\
(\sim 6 \%) \text { so dose adjustment in } \\
\text { renal dysfunction is unlikely }\end{array}$ & $\begin{array}{l}\text { - Docetaxel is not dialyzed } \\
\text { »Rapid half-life of } 4 \text { minutes } \\
\text { »Rapidly bound to plasma proteins } \\
\text { »PK data are unaffected, with no difference in plasma } \\
\text { concentrations when compared to patients with normal } \\
\text { renal function } \\
\text { »Can give before or after HD } \\
\text { - No effect of CAPD on PK of docetaxel }\end{array}$ \\
\hline Etoposide ${ }^{d}$ & $\begin{array}{l}\text { - No data available from } \\
\text { package labeling }\end{array}$ & $\begin{array}{l}\text { - Administer } 50 \% \text { of usual dose before or after HD } \\
\text { » PK parameters similar to that for normal renal function } \\
\text { patients. Dose escalation recommended. } \\
\text { »Not removed by HD } \\
\text { »Efficacy maintained, but monitor closely for hematologic } \\
\text { toxicity } \\
\text { - Peritoneal dialysis: administer } 50 \% \text { of dose; post-HD dose not } \\
\text { necessary } \\
\text { - CRRT: Administer } 75 \% \text { of dose }\end{array}$ \\
\hline Gemcitabine ${ }^{e}$ & $\begin{array}{l}\text { - No dose adjustments } \\
\text { based on manufacturer } \\
\text { labeling; use with caution } \\
\text { in preexisting renal } \\
\text { dysfunction } \\
\text { - Discontinue if severe } \\
\text { renal toxicity or hemolytic } \\
\text { uremic syndrome during } \\
\text { gemcitabine treatment }\end{array}$ & $\begin{array}{l}\text { - Initial dose reduction recommended ( } 20 \%-40 \% \text { reduction) } \\
\text { - Rapidly deaminated after administration to inactive metabolite } \\
\text { dFdU (< } 10 \% \text { parent drug eliminated via urine) } \\
\text { - Found to be safe in HD on days without HD } \\
\text { - } 90 \% \text { of dFdU is eliminated by urine and can be delayed (5- to } \\
10-\text { fold prolongation in elimination half-life) } \\
\text { - Unknown if gemcitabine is removed by HD, but dFdU is } \\
\text { removed by HD } \\
\text { - Recommended to start HD 6-12 hours after gemcitabine } \\
\text { administration }\end{array}$ \\
\hline Irinotecan ${ }^{f}$ & $\begin{array}{l}\text { - Use in HD not recommended } \\
\text { by the manufacturer }\end{array}$ & $\begin{array}{l}\text { - Reduce weekly dose from } 125 \mathrm{mg} / \mathrm{m}^{2} \text { to } 50 \mathrm{mg} / \mathrm{m}^{2} \text { and } \\
\text { administer after hemodialysis or on nondialysis days } \\
\text { " Even with dose reductions, reports of neutropenia (grades } \\
\text { 1-4) reported } \\
\text { » If tolerated, may increase dose to } 80 \mathrm{mg} / \mathrm{m}^{2} \\
\text { " Not dialyzable } \\
\text { "SN-38 is significantly delayed in renal failure and partially } \\
\text { dialyzable (up to } 50 \% \text { ) } \\
\text { - Uremic toxins may inhibit OATP1B1, delaying SN-38 } \\
\text { transportation from the hepatocyte }\end{array}$ \\
\hline
\end{tabular}




\section{Table 2. Chemotherapy Dose Adjustments in Hemodialysis (cont.)}

$\begin{array}{ll}\text { Medication } & \begin{array}{l}\text { Package insert } \\ \text { recommendation }\end{array} \\ \text { Paclitaxel }^{g} & \begin{array}{l}\text { - No dosage adjustments } \\ \text { provided in the } \\ \text { manufacturer labeling }\end{array} \\ & \begin{array}{l}\text { Not dialyzable; used before } \\ \text { or after hemodialysis }\end{array} \\ \text { Nab-paclitaxel }^{\mathrm{h}} & \text { - Not studied } \\ \text { Pemetrexed }^{\text {N }} & \text { - Not recommended }\end{array}$

Temozolomidej $\quad$ Not studied

Topotecank

Vinorelbine
- IV: avoid use in HD and CAPD; CRRT: administer $0.75 \mathrm{mg} / \mathrm{m}^{2}$

- po: $\mathrm{CrCl}<30 \mathrm{~mL} / \mathrm{min}$ reduce dose to $0.6 \mathrm{mg} / \mathrm{m}^{2} /$ day and may increase by $0.4 \mathrm{~g} / \mathrm{m}^{2} /$ day if no severe hematologic or GI toxicities occur

- No dosage adjustments provided in the manufacturer labeling

\section{Literature recommendations}

- Extensively metabolized by CYP and excreted mainly in bile

- Paclitaxel PK in HD patients is comparable to that for patients with normal renal function

- Studied primarily in the gynecology/oncology population

- No available information

- Not dialyzable; use before or after hemodialysis

- Not dialyzable

- Contraindicated in eGFR $<45 \mathrm{~mL} / \mathrm{min}$

- Retrospective evaluation of pemetrexed-induced renal injury, all with eGFR $>45 \mathrm{~mL} / \mathrm{min}$, was associated with severe myelosuppression and hospitalization

- If pemetrexed is to be used in renal dysfunction, all risk factors for AKI should be corrected

- One case of NSCLC with eGFR 25-55 mL/min

»Four cycles of carboplatin and pemetrexed administered, then maintenance of pemetrexed of $500 \mathrm{mg} / \mathrm{m}^{2}$ every 3 weeks. At dose 14 dose reduced to $400 \mathrm{mg} / \mathrm{m}^{2}$, at dose 16 interval extended to q4wk; received 51 total doses of pemetrexed

- The need for dose adjustment and dialyzability unknown

- Patients with mild to moderate renal dysfunction have similar PK compared to normal renal function; severe renal dysfunction has not been studied

- IV topotecan is dialyzable, with one case reporting $60 \%$ removal with HD

- Administer on non-HD days or after HD

- A relationship between topotecan exposure (AUC) and myelotoxicity cannot be inferred

- Recommend initial dose reduction to $20 \mathrm{mg} / \mathrm{m}^{2} / \mathrm{wk}$ due to neutropenia seen with $25 \mathrm{mg} / \mathrm{m}^{2} / \mathrm{wk}$

- No data of oral vinorelbine

- Removal by HD not studied; recommended to give after HD sessions or on nondialysis days

Note. $\mathrm{PI}=$ package insert; $\mathrm{HD}=$ hemodialysis; $\mathrm{CrCl}$ = creatinine clearance; GFR = glomerular filtration rate;

$\mathrm{CAPD}=$ continuous ambulatory peritoneal dialysis; CRRT = continuous renal replacement therapy;

$\mathrm{PK}=$ pharmacokinetic; $\mathrm{dFdU}=2^{\prime}, 2^{\prime}$-difluorodeoxyuridine; $\mathrm{CYP}=$ cytochrome P450; eGFR = estimated GFR; $\mathrm{AKI}=$ acute kidney injury; IV = intravenous; $A \cup C$ = area under the curve; po = orally; GI = gastrointestinal.

aBristol-Myers Squibb (2010a); Charlier, Kintz, Dubois, \& Plomteux (2004); Janus, Thariat, Boulanger, Deray, \& LaunayVacher (2010); Watanabe et al. (2003).

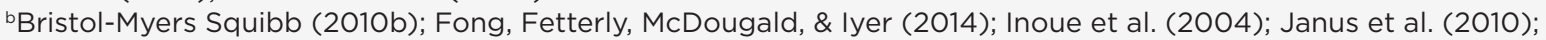

Takezawa, Okamoto, Fukuoka, \& Nakagawa (2008); Tanaka (2015).

cHochegger, Lhotta, Mayer, Czejka, \& Hilbe (2007); Janus et al. (2010); Kaneda, Okamoto, \& Nakagawa (2012); SanofiAventis (2015); Yang et al. (2015).

'Bristol-Myers Squibb (2016); Inoue et al. (2004); Janus et al. (2010); Watanabe et al. (2003).

eEli Lilly (2014); Ide et al. (2011); Janus et al. (2010); Kiani et al. (2003); Masumori et al. (2008); Siefker-Radtke et al. (2016); Takakura et al. (2014).

${ }^{f}$ Ashizawa et al. (2010); Czock, Rasche, Boesler, Shipkova, \& Keller (2009); Fujita et al. (2011); Kim, Kim, Chung, \& Park (2009); Pfizer (2016a); Togashi et al. (2011).

'Bristol-Myers Squibb (2011); Janus et al. (2010); Tanaka (2015).

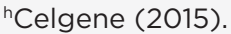

'Brandes, Grossman, \& Ahmad (2006); Eli Lilly (2013); Ohana, Brahim, \& Ibrahim (2016); Rombola et al. (2015).

iJanus et al. (2013); Jen et al. (2000); Merck (2008).

kHerrington, Figueroa, Kirstein, Zamboni, \& Stewart (2001); Novartis (2015); O’Reilly et al. (1996).

'GlaxoSmithKline (2002); Janus et al. (2010); Sahni, Choudhury, \& Ahmed (2009). 
ing cisplatin as a means of reversing the overdose, which ultimately led to mortality. Despite immediate HD and subsequent plasmapheresis, there were no improvements in toxicity related to the drug concentration of cisplatin (Charlier, Kintz, Dubois, \& Plomteux, 2004).

Carboplatin: Carboplatin dosing is unique as it uses the Calvert formula, which calculates a dose that targets a specific area under the curve (AUC). This formula is based on a patient's glomerular filtration rate (GFR). The dose equals the desired AUC multiplied by the sum of 25 and the GFR (Calvert et al., 1989). The GFR represents the extent to which the blood is being actively filtered by the kidneys. Patients on HD no longer have functioning kidneys, and as such, the GFR in the Calvert formula for a patient on HD is set to zero. The target AUC is specific to each regimen and can range from 2 to 7.

Table 2 summarizes several case studies evaluating the use of carboplatin in ESRD patients. Some of these reports include patients receiving HD after the completion of the carboplatin infusion. Approximate AUCs obtained from these patients trended lower than the targeted AUC. This may have been attributed to the HD removing active platinum before goal levels in the plasma were reached (Takezawa, Okamoto, Fukuoka, \& Nakagawa, 2008). Another group of case studies showed results closer to target AUCs. These cases timed the HD on the day after the carboplatin infusion potentially removing less active drug. Dosing the day after HD provided a desirable therapeutic outcome and was well tolerated (Kodama et al., 2010, Oguri et al., 2010).

In a comprehensive review paper, the authors concluded carboplatin should be dosed with the Calvert formula using a GFR of 0 and administered 12 to 24 hours before HD (Janus et al., 2010). Carboplatin can be tolerable and appropriate for cancer patients receiving HD the day after treatment as long as proper follow-up is provided.

\section{Taxanes}

The taxanes, often used in regimens with the platinum agents, are primarily metabolized via the hepatic system. Taxanes work by inhibiting the polymerization of microtubules, which prevents cells from undergoing mitosis.
Paclitaxel: Generally, ESRD patients can receive full-dose paclitaxel and maintain similar plasma concentrations before and after HD as it is not dialyzable (Baur, Fazeny-Doerner, Olsen, \& Dittrich, 2008; Ide et al., 2011; Kodama et al., 2010; Tomita, Kurata, Aoki, Tanaka, \& Kazama, 2001; Watanabe et al., 2002; Yoshida, Sumi, Abe, \& Ishiko, 2009).

Docetaxel: Docetaxel is also not dialyzable, which allows it to be infused before or after HD and without a dose adjustment. The body eliminates the majority of docetaxel via fecal excretion (Sanofi-Aventis, 2015).

Nab-paclitaxel: Nab-paclitaxel is an albuminbound form of paclitaxel with only $4 \%$ of the drug excreted as unchanged drug and less than $1 \%$ as its main metabolites (Celgene, 2015). Considering the metabolic and elimination pathways occur predominately in the liver, dose adjustments are not required for initiating treatment in patients with ESRD, as seen in Table 2.

\section{Topoisomerase I Inhibitors}

Irinotecan: Irinotecan binds topoisomerase I and forms a complex with DNA strands, preventing DNA from properly replicating and repairing itself. Nearly $80 \%$ of irinotecan's elimination is done without the kidneys (Pfizer, 2016a). The metabolism of irinotecan, however, is complex and dependent on pharmacogenomics. The first step in its metabolism involves the formation of SN-38, a nondialyzable, active metabolite further broken down by UGT1A1 via enzymatic glucuronidation occurring in the liver. Some patients have alleles affecting the expression of this enzyme leading to higher SN-38 levels, and therefore more profound neutropenia (Togashi et al., 2011). Current recommendations from the available literature do not call for proactive UGT1A1 genotyping for patients beginning treatment with irinotecan (Evaluation of Genomic Applications in Practice and Prevention Working Group, 2009).

One case study discussed a small cell lung cancer patient who received irinotecan at a dose of $100 \mathrm{mg} / \mathrm{m}^{2}$ weekly for 3 weeks every 28 days (Kim, Kim, Chung, \& Park, 2009). Hemodialysis occurred approximately 1 day after each infusion. Treatment was tolerated with grade 2 fatigue and anorexia, and one grade 3 neutropenia event. The 
patient achieved a complete response. However, another report documented a small cell lung cancer patient who was scheduled to receive a similar frequency of irinotecan at a lower dose of $50 \mathrm{mg} /$ $\mathrm{m}^{2}$, but could not continue treatment after the first dose due to grade 4 neutropenia and a worsening of performance status.

Pharmacogenomics played a role in this highgrade adverse event as the patient had the suspect alleles. Pharmacokinetic (PK) studies performed documented an AUC of the active metabolite SN38 approximately 3 times greater than that for those with normal renal function, likely because $\mathrm{SN}-38$ is not dialyzable and the genetic predisposition of the patient in question (Togashi et al., 2011).

The caveat for using irinotecan in patients receiving $\mathrm{HD}$ is the consideration of possible pharmacogenomic alleles that will change the metabolism of the active metabolite. As long as the patient does not have the alleles that cause a decrease in metabolism of SN-38, it is plausible to consider the use of irinotecan with a reduced dose, and titrate accordingly.

Topotecan: Topotecan binds with DNA and topoisomerase I, stabilizing the cleavable complex preventing religation, thus interrupting DNA replication. There are both IV and oral formulations. The IV drug is excreted by the kidneys with $51 \%$ excreted in urine, whereas only $20 \%$ of the oral formulation is excreted in urine (Novartis, 2015). The package labeling recommends dose reductions in renal dysfunction, as seen in Table 2.

A case series of 28 patients with documented solid tumors stratified them based on renal function: Group 1 with creatinine clearance $(\mathrm{CrCl}) \geq$ $60 \mathrm{~mL} / \mathrm{min}$, Group 2 with $\mathrm{CrCl}=40-59 \mathrm{~mL} / \mathrm{min}$, Group 3 with $\mathrm{CrCl}=20-39 \mathrm{~mL} / \mathrm{min}$, and Group 4 with $\mathrm{CrCl}<20 \mathrm{~mL} / \mathrm{min}$. Dosing of topotecan were $1.5 \mathrm{mg} / \mathrm{m}^{2} /$ day for 5 days for Group 1 and $0.5 \mathrm{mg} /$ $\mathrm{m}^{2} /$ day for 5 days for the remaining groups with escalation to 1 and $1.5 \mathrm{mg} / \mathrm{m}^{2}$. There were two patients with severe renal impairment and one experienced dose-limiting thrombocytopenia during his/her first cycle of $0.5 \mathrm{mg} / \mathrm{m}^{2} /$ day. A reduction in clearance was observed in patients with a $\mathrm{CrCl}$ $<60 \mathrm{~mL} / \mathrm{min}$; however, no relationship between AUC and myelotoxicity was observed. A reduction in the initial dose of topotecan by $50 \%-75 \%$ is rec- ommended in patients with severe renal dysfunction (O'Reilly et al., 1996).

One case report on an ovarian carcinoma patient with ESRD observed a $60 \%$ reduction of topotecan administered on nondialysis days and saw a 4-fold increase in clearance while on HD and systemic clearance similar to that for patients with normal renal function. Despite the increase in clearance, initial observations of plasma concentrations after HD increased. No further investigation was pursued on this rebound effect given logistical concerns. Grade 4 neutropenia and grade 3 thrombocytopenia were observed in the patient without the support of growth factors (Herrington et al., 2001).

\section{Pyrimidine Antagonist}

Gemcitabine: Gemcitabine, a prodrug, exerts its antineoplastic effects via its active metabolites acting as a pyrimidine nucleoside analog and inhibiting ribonucleotide reductase, lessening the amount of deoxynucleoside triphosphates available for DNA formation. The parent compound, metabolized by deamination that occurs in the liver, kidneys, and other tissues, becomes $2^{\prime}, 2^{\prime}$-difluorodeoxyuridine (dFdU; Kiani et al., 2003). According to prescribing information, over $90 \%$ of the drug is excreted in the urine as $\mathrm{dFdU}$ and less than $10 \%$ as the parent compound (Eli Lily, 2014). Much of the literature for dose adjustment in HD is derived from the pancreatic cancer patient population.

One case study documented a urothelial carcinoma patient on HD who received treatment with biweekly gemcitabine dosed at $2,250 \mathrm{mg} / \mathrm{m}^{2}$ along with paclitaxel. The gemcitabine was reduced by $10 \%$ and administered 24 hours before HD. The AUCs were measured for both and were similar to those for a patient with normal renal function. No grade 3 or 4 adverse events were reported, and the patient did not have any documented progression 1 year out from publication (Ide et al., 2011).

A case report on a patient with pancreatic cancer who received $1,000 \mathrm{mg} / \mathrm{m}^{2}$ gemcitabine doses on days 1 and 10 for 2 cycles with HD approximately 24 hours after each infusion evaluated levels of gemcitabine and its inactive metabolite, dFdU. Peak serum concentrations and AUC for gemcitabine matched closely to values reported in patients with normal renal function. Interestingly, 
dFdU elimination was distinctly decreased for this patient, leading to an AUC approximately 10 times that observed in a patient with normal renal function. Levels of dFdU are known to be eliminated via the urine and the levels in this patient were normalized once HD occurred. The cytotoxic and active metabolites levels more closely mirrored and plateaued like the levels of the parent compound (Kiani et al., 2003).

Another case series is available in which levels of gemcitabine and $\mathrm{dFdU}$ were measured for two pancreatic cancer patients on $\mathrm{HD}$ receiving gemcitabine at $1,000 \mathrm{mg} / \mathrm{m}^{2}$. Similar results were reported where the AUC and peak concentrations of the parent gemcitabine matched those of a population with normal renal function. As previously reported, the dFdU levels were most impacted by the compromised renal function. Until HD was administered, these levels remained notably higher than those for patients with normal renal function (Masumori et al., 2008).

Data regarding increased exposure to this metabolite is limited. Concern exists with gemcitabine's use due to the delayed elimination and higher AUC of dFdU. The current literature indicates that $\mathrm{dFdU}$ is a noncytotoxic metabolite and patients with increased exposure do not have an increase in adverse events. Based on this, gemcitabine can be used if needed in the ESRD population without an initial dose reduction as long as careful toxicity monitoring is performed. Gemcitabine can be administered 6 to 12 hours before $\mathrm{HD}$ to prevent the possible accumulation of $\mathrm{dFdU}$.

\section{Topoisomerase II Inhibitor}

Etoposide: Etoposide acts by binding with DNA and topoisomerase II leading to the destruction of DNA. This drug is excreted by the kidneys with $56 \%$ of a dose found in the urine $(45 \%$ as unchanged drug). Bile and stool account for the remaining $44 \%$ that is excreted (Bristol-Myers Squibb, 2016). With respect to the amount of etoposide eliminated by the kidneys, dose reductions for patients on HD are prudent with an effort to keep antitumor activity.

A case series of five ESRD patients who received etoposide at $50 \mathrm{mg} / \mathrm{m}^{2}$ on days 1,3 , and 5 is available (Watanabe et al., 2003). Two of the five patients tolerated a dose escalation to the full 100 $\mathrm{mg} / \mathrm{m}^{2}$ dose of etoposide. All five patients experienced grade 2 or greater anemia and neutropenia starting with the first cycle with full recovery in all cases. Despite a low sample size, this is much higher than the incidence of $33 \%$ or less reported in the package labeling for anemia in the general population for etoposide.

Another study evaluated three small cell cancer patients undergoing HD who received etoposide at a 50\% dose reduction and had HD 1 hour following the etoposide infusion. These patients received etoposide on days 1 and 3 to ensure it was tolerated appropriately. The authors noted that plasma concentrations obtained were comparable with the levels of patients with normal renal function (Inoue et al., 2004).

Etoposide dose reductions are still pertinent since a small amount of the drug is excreted via the urine and a prolonged half-life can be seen. As it seems, HD does not primarily remove etoposide; therefore, etoposide can be administered before or after HD sessions.

\section{Triazine}

Temozolomide: Temozolomide undergoes spontaneous conversion through hydrolysis to the active alkylatingagent, methyl-(triazene-1-yl)-imidazole4-carboxamide, which methylates DNA at the $\mathrm{O}^{6}, \mathrm{~N}^{7}$ guanine position leading to double-strand breaks in DNA. Approximately $38 \%$ is excreted as parent drug in the urine (Merck, 2008).

There is a paucity of published literature in regards to the dosing of temozolomide in the setting of renal dysfunction. One PK evaluation of 445 patients undergoing trials in the treatment of tumors, including brain metastasis, lung cancer, and breast cancer, concluded that patients with mild to moderate renal dysfunction have similar PK as patients with normal renal function. No evaluation of severe renal dysfunction was reported (Jen et al., 2000).

\section{Vinca Alkaloid}

Vinorelbine: Vinorelbine, a semisynthetic vinca alkaloid, prevents the polymerization of tubulin and formation of mitotic spindle. The majority of vinorelbine is excreted in feces (46\%), with $18 \%$ found in urine. A fraction of vinorelbine is excreted through the kidneys. There are no manufactur- 
er recommendations for initial dose adjustment (GlaxoSmithKline, 2002).

In a comprehensive review paper, the authors affirm the recommendations to reduce initial doses to $20 \mathrm{mg} / \mathrm{m}^{2} /$ week. Higher doses of $25 \mathrm{mg} / \mathrm{m}^{2} /$ week observed neutropenia. There is no current data evaluating oral vinorelbine. The $\mathrm{PK}$ data with vinorelbine in HD has not been studied; therefore, recommendations are to administer after HD sessions or on nondialysis days (Janus et al., 2010).

\section{Antimetabolite}

Pemetrexed: Pemetrexed, like methotrexate, is an antifolate. It impairs cell division by inhibiting thymidylate synthase, dihydrofolate reductase, and glycinamide ribonucleotide formyltransferase. The inhibition of these enzymes help prevent the de novo creation of purine nucleotides. Approximately $70 \%$ to $90 \%$ of unchanged pemetrexed is cleared through the urine (Eli Lilly, 2013).

A patient with normal renal function (a $\mathrm{CrCl}$ of around $75 \mathrm{~mL} /$ minute) was being treated for mesothelioma with pemetrexed at $500 \mathrm{mg} / \mathrm{m}^{2}$ and cisplatin (Brandes, Grossman, \& Ahmad, 2006). This patient developed acute tubular necrosis following his second cycle and was admitted. In an effort to prevent further toxicity, HD was administered. The levels of pemetrexed in the post dialysate fluid compared to plasma levels pre- and post-HD led the authors to conclude that pemetrexed is poorly dialyzable. Pemetrexed should not be considered for patients without adequate renal function.

A case report of a 70-year-old female with stage IVa non-small cell lung cancer (NSCLC) with $\mathrm{CrCl}<45 \mathrm{~mL} / \mathrm{min}$ received four cycles of carboplatin and pemetrexed then maintenance with pemetrexed at $500 \mathrm{mg} / \mathrm{m}^{2}$ every 3 weeks. At dose 14 the dose was reduced to $400 \mathrm{mg} / \mathrm{m}^{2}$ and at dose 16 the interval was extended to every 4 weeks. The patient received 51 doses of pemetrexed with estimated GFR (eGFR) ranging from $25-55 \mathrm{~mL} / \mathrm{min}$. This is one of the few cases reported of pemetrexed administration in a patient with $\mathrm{CrCl}<45 \mathrm{~mL} / \mathrm{min}$ (Ohana, Brahim, \& Ibrahim, 2016). Dialysis remains a contraindication for patients receiving pemetrexed, and giving pemetrexed to a patient with a $\mathrm{CrCl}<45$ could result in serious chemotherapy toxicities and should be strongly avoided.

\section{TARGETED AGENTS}

\section{Monoclonal Antibodies}

The therapeutic class of monoclonal antibodies (mAbs) has become an important component of therapeutic regimens in oncology. Antibodies function as individual cytotoxic agents and utilize several mechanisms, including the antigen-binding fragment (Fab) and/or Fc domains of the molecule, serving as a carrier, or by ferrying the toxic cargo to cancer cells. Monoclonal antibodies have several advantages compared to the traditional chemotherapeutic agents, including a prolonged half-life and high target specificity (Glassman \& Balthasar, 2014).

Given the size of mAbs, their elimination follows a unique pathway. Target-mediated drug disposition is described as the disposition of mAbs when bound to their molecular target, leading to degradation of the mAb-target complex. Targetmediated drug disposition (TMDD) is mediated either through fluid phase or receptor-mediated endocytosis (Panoilia et al., 2015). Monoclonal antibody-target complexes initiate endocytosis and intracellular elimination of the antibody. As more doses of $\mathrm{mAb}$ are administered, target receptor occupancy becomes saturated, leading to a decrease in apparent volume of distribution (Vd). A decrease in $\mathrm{Vd}$ results in a decrease in the rate of antibody clearance. This follows a nonlinear, dose-dependent PK model, which does not affect renal clearance (Glassman \& Balthasar, 2014).

\section{Targeted Therapy}

Bevacizumab: Bevacizumab (Avastin), a recombinant humanized $\mathrm{mAb}$, is a vascular endothelial growth factor (VEGF) inhibitor (Genentech, 2016a; Table 3). The main elimination pathway is proteolytic catabolism throughout the body (linear, nonspecific clearance) and not hepatic metabolism or renal excretion (Panoilia et al., 2015). When bevacizumab was administered in a 23-year-old with metastatic renal cell carcinoma undergoing $\mathrm{HD}$, the authors concluded that $5 \mathrm{mg} /$ $\mathrm{kg}$ dosing could be used. Based on the plasma levels drawn, they also concluded that bevacizumab is not dialyzable; therefore, the timing of HD in relation to the infusion is not significant (GarnierViougeat et al., 2007). Bevacizumab can be given without dose reduction due to its larger molecular 


\section{Table 3. Intravenous Targeted Therapy for Lung Cancer}

\begin{tabular}{|c|c|c|c|c|}
\hline Medication & Indication & Dose & Metabolism/elimination & Molecular weight \\
\hline Bevacizumab & $\begin{array}{l}\text { - Nonsquamous NSCLC with } \\
\text { carboplatin and paclitaxel for first- } \\
\text { line treatment of unresectable, } \\
\text { locally advanced, recurrent or } \\
\text { metastatic disease }\end{array}$ & $\begin{array}{l}15 \mathrm{mg} / \mathrm{kg} \text { once } \\
\text { every } 3 \text { weeks }\end{array}$ & $\begin{array}{l}\text { Proteolytic catabolism } \\
\text { (linear, nonspecific } \\
\text { clearance); half-life is } \\
20 \text { days }\end{array}$ & $149 \mathrm{kDa}$ \\
\hline Necitumumab & $\begin{array}{l}\text { - EGFR antagonist in combination } \\
\text { with gemcitabine and cisplatin for } \\
\text { first-line treatment of patients with } \\
\text { metastatic squamous NSCLC; not } \\
\text { indicated for nonsquamous NSCLC }\end{array}$ & $\begin{array}{l}800 \mathrm{mg} \text { on } \\
\text { day } 1 \text { and } 8 \text { of } \\
\text { every } 3 \text { weeks }\end{array}$ & $\begin{array}{l}\text { Saturable receptor- } \\
\text { mediated clearance; } \\
\text { half-life is } 7 \text { days }\end{array}$ & $144.8 \mathrm{kDa}$ \\
\hline Ramucirumab & $\begin{array}{l}\text { - In combination with docetaxel for } \\
\text { the treatment of metastatic NSCLC } \\
\text { with disease progression on or after } \\
\text { platinum-based chemotherapy. } \\
\text { - Patients with EGFR or ALK } \\
\text { genomic tumor aberrations should } \\
\text { have disease progression on } \\
\text { FDA-approved therapy for these } \\
\text { aberrations prior to receiving } \\
\text { ramucirumab }\end{array}$ & $\begin{array}{l}10 \mathrm{mg} / \mathrm{kg} \text { once } \\
\text { every } 3 \text { weeks }\end{array}$ & $\begin{array}{l}\text { Saturable receptor- } \\
\text { mediated clearance; } \\
\text { half-life is } 14 \text { days }\end{array}$ & $147 \mathrm{kDa}$ \\
\hline
\end{tabular}

weight of $149 \mathrm{kDa}$, which would explain its inability to be dialyzed (Inauen et al., 2007).

Necitumumab: Necitumumab (Portrazza) is a recombinant human immunoglobulin G1 (IgG1) epidermal growth factor receptor (EGFR) $\mathrm{mAb}$ that binds to the ligand binding site of the EGFR receptor to prevent receptor activation and downstream signaling (Thatcher et al., 2015). There is no available literature through PubMed or from the manufacturer with regards to dosing and experience in patients undergoing dialysis (Eli Lilly, 2015; Table 4).

Ramucirumab: Ramucirumab (Cyramza) is a recombinant $\mathrm{mAb}$ that inhibits vascular endothelial growth factor receptor 2 (VEGFR2) and leads to inhibition of ligand-induced proliferation and migration of endothelial cells (Spratlin,
2010). VEGFR2 inhibition results in reduced tumor vascularity and growth (Fuchs et al., 2014). There is no available literature through PubMed or from the manufacturer with regards to dosing and experience in patients undergoing dialysis (Eli Lilly, 2017).

\section{Oral Targeted Therapy}

The oral tyrosine kinase EGFR and ALK (anaplastic lymphomas kinase) inhibitors have truly revolutionized the treatment of patients with NSCLC. Patients harboring these mutations have the ability to be treated with targeted oral agents before cytotoxic chemotherapy or immunotherapy. Of the available eight agents listed in Table 5, there is little to no renal involvement with regards to metabolism or excretion. With that being said,

\begin{tabular}{|c|c|c|c|c|}
\hline Drug & Mild impairment & Moderate impairment ${ }^{a}$ & Severe impairment ${ }^{b}$ & Dialysis \\
\hline Bevacizumab & $\mathrm{N} / \mathrm{A}$ & N/A & N/A & N/A \\
\hline Necitumumab & N/A & N/A & N/A & N/A \\
\hline Ramucirumab & N/A & N/A & N/A & N/A \\
\hline
\end{tabular}

Note. IV = intravenous.

${ }^{a}$ Creatinine clearance $>30 \mathrm{~mL} / \mathrm{min}$ not requiring dialysis.

${ }^{b}$ Creatinine clearance $15-29 \mathrm{~mL} / \mathrm{min}$. 
Table 5. Targeted Therapy for Lung Cancer

\begin{tabular}{|c|c|c|c|c|}
\hline Medication & Indication & Dose & Excretion & Metabolism \\
\hline Afatinib & $\begin{array}{l}\text { - First-line treatment of patients with } \\
\text { metastatic NSCLC with EGFR exon } \\
19 \text { deletions or exon } 21 \text { (L858R) } \\
\text { substitutions } \\
\text { - Patients with metastatic squamous } \\
\text { NSCLC who have progressed after } \\
\text { platinum-based chemotherapy }\end{array}$ & 40 mg once daily & $\begin{array}{l}\text { Feces }(85 \%) \\
\text { urine }(4 \%)\end{array}$ & $\begin{array}{l}\text { Minimal enzymatic } \\
\text { metabolism }\end{array}$ \\
\hline Brigatinib & $\begin{array}{l}\text { Patients with } A L K+\text { metastatic NSCLC } \\
\text { who have progressed or are intolerant } \\
\text { to crizotinib }\end{array}$ & 90 mg once daily & $\begin{array}{l}\text { Feces }(65 \%) \\
\text { urine }(25 \%)\end{array}$ & $\begin{array}{l}\text { Hepatic (CYP2C8, } \\
\text { CYP3A4) }\end{array}$ \\
\hline Erlotinib & $\begin{array}{l}\text { - Patients with EGFR+ metastatic } \\
\text { NSCLC with exon } 19 \text { deletions or exon } \\
21 \text { (L858R) substitutions receiving } \\
\text { first-line, maintenance, or second- or } \\
\text { greater-line therapy after progression } \\
\text { following at least one prior regimen }\end{array}$ & 150 mg once daily & $\begin{array}{l}\text { Feces }(83 \%) \\
\text { urine }(8 \%)\end{array}$ & Hepatic \\
\hline Gefitinib & $\begin{array}{l}\text { - Patients with first-line metastatic } \\
\text { NSCLC who have EGFR exon } \\
19 \text { deletions or exon } 21 \text { (L858R) } \\
\text { substitutions }\end{array}$ & 250 mg once daily & $\begin{array}{l}\text { Feces }(86 \%) \\
\text { urine }(<4 \%)\end{array}$ & Hepatic \\
\hline Osimertinib & $\begin{array}{l}\text { - Patients with metastatic NSCLC who } \\
\text { have EGFR T790M mutations and } \\
\text { have progressed on or after EGFR TKI } \\
\text { therapy }\end{array}$ & 80 mg once daily & $\begin{array}{l}\text { Feces }(68 \%) \text {; } \\
\text { urine }(14 \%)\end{array}$ & Hepatic \\
\hline Crizotinib & $\begin{array}{l}\text { - Patients with metastatic } A L K+\text { or } \\
\text { ROS1+ NSCLC }\end{array}$ & 250 mg twice daily & $\begin{array}{l}\text { Feces }(63 \%) \\
\text { urine }(22 \%)\end{array}$ & $\begin{array}{l}\text { Hepatic } \\
\text { (CYP3A4/5) }\end{array}$ \\
\hline Ceritinib & $\begin{array}{l}\text { Patients with } A L K+\text { metastatic NSCLC } \\
\text { who have progressed or are intolerant } \\
\text { to crizotinib }\end{array}$ & 750 mg once daily & $\begin{array}{l}\text { Feces }(92 \%) \\
\text { urine }(1 \%)\end{array}$ & Hepatic \\
\hline Alectinib & $\begin{array}{l}\text { Patients with } A L K+\text { metastatic NSCLC } \\
\text { who have progressed or are intolerant } \\
\text { to crizotinib }\end{array}$ & 600 mg twice daily & $\begin{array}{l}\text { Feces }(98 \%) \\
\text { urine }(<0.5 \%)\end{array}$ & Hepatic \\
\hline
\end{tabular}

there is limited PK and pharmacodynamic burden on the kidneys; however, there is also a paucity of manufacturer-recommended renal dose adjustments, as noted in Table 6 .

Erlotinib: More literature and experience exists in dosing the EGFR inhibitors in dialysis patients than there is in dosing patients with the ALK inhibitors. A PK analysis of the active metabolite of erlotinib (Tarceva) was performed and compared in three patients with NSCLC and chronic renal failure (CRF) undergoing noncancerrelated dialysis and five patients with NSCLC with normal organ function. The three intervention patients were all offered unadjusted erlotinib instead of chemotherapy due to the greater perceived benefit, even though their EGFR mutation status was negative or unknown. Two of the three patients experienced diarrhea as an adverse event, with one of those patients also having nausea and the remaining patient having no major toxicities while on treatment. Pharmacokinetic analyses among the case and control patients were similar, indicating that erlotinib was not affected by dialysis. All three dialysis patients had a response to therapy, with two having stable disease and one patient having a partial response (Togashi et al., 2010). The manufacturer also shared information about patients on chronic dialysis who tolerated full-dose erlotinib and achieved stable disease for 11 months as first-line treatment of NSCLC. No further outcomes were described (Genentech/Astellas Oncology, 2016). 
Table 6. Renal Dose Adjustments for Targeted Lung Cancer Therapy per Package Inserts

\begin{tabular}{|c|c|c|c|c|}
\hline Drug & Mild impairment & Moderate impairment ${ }^{a}$ & Severe impairment ${ }^{b}$ & Dialysis \\
\hline Afatinib & N/A & N/A & $30 \mathrm{mg}$ once daily & $\mathrm{N} / \mathrm{A}$ \\
\hline Brigatinib & N/A & N/A & N/A & $\mathrm{N} / \mathrm{A}$ \\
\hline Erlotinib & N/A & N/A & N/A & N/A \\
\hline Gefitinib & N/A & N/A & N/A & N/A \\
\hline Osimertinib & N/A & N/A & N/A & N/A \\
\hline Crizotinib & N/A & N/A & 250 mg once daily & N/A \\
\hline Ceritinib & N/A & N/A & N/A & N/A \\
\hline Alectinib & N/A & N/A & N/A & N/A \\
\hline
\end{tabular}

Gefitinib: In a similar manner to erlotinib, there are case reports and information from the manufacturer on gefitinib (Iressa) in patients who are receiving HD. The earliest reported case from 2007 was that of a 58-year-old, never-smoking female on HD. Molecular testing revealed an EGFR exon 19 deletion mutation. The patient started full-dose therapy with gefitinib and continued her dialysis. Blood samples taken around dialysis revealed that the $\mathrm{PK}$ pattern was similar to that of a patient with normal renal function, stating that $88.7 \%$ of the gefitinib was kept in the plasma through dialysis. She achieved a response to therapy throughout the 13-month course and had no significant adverse events (Shinagawa et al., 2007).

Two other case reports are also described in elderly never-smoking male patients. In the first case, a 70-year-old patient on HD was treated with full-dose gefitinib for his recurrent EGFR exon 19 deletion-positive NSCLC. He demonstrated a complete response to treatment with no significant adverse events (Del Conte et al., 2014). In the second case, a 72-year-old patient on continuous ambulatory peritoneal dialysis (CAPD) was also treated with full-dose gefitinib for recurrent EGFR exon 19 deletion-positive NSCLC metastatic to the brain. Blood samples obtained during the patient's treatment around CAPD were deemed to reach steady state by day 16 , and drug concentrations were minimally impacted by CAPD. The patient developed grade 2 diarrhea as his only side effect and had disease improvement. (Yamaguchi, Isogai, \& Okamura, 2015). However, there are considerable differences in the contents of the dialy- sate and the timing and volume of dialysis fluid exchange among individual CAPD patients, which make these results difficult to generalize.

Afatinib: Unlike the previously mentioned therapies, afatinib (Gilotrif) had no information from the manufacturer with regards to PK studies or experience in patients receiving HD. However, there have been case reports from which interpretations of safety and efficacy can be drawn. The first case report published was on a 60-year-old female never smoker with unknown EGFR status and CRF. The patient observed clinical benefit and prolonged response of disease for 7 years. Upon progression, the patient was placed on afatinib at $30 \mathrm{mg}$ daily. The patient tolerated therapy well through continued dialysis for 2 months, experiencing only mild asthenia. Therapy was then increased to full dose at $40 \mathrm{mg}$ daily (Boehringer Ingelheim, 2016).

Unfortunately, after only a few days, due to the appearance of significant asthenia and vomiting and nausea, the patient self-discontinued therapy and was off therapy until she had progression of disease in March 2012 (Bersanelli, Tiseo, Artioli, Lucchi, \& Ardizzoni, 2014). This is the only available example of a patient who experienced side effects severe enough to discontinue therapy among the case examples for targeted therapy during dialysis.

Another more recent case report recounted three male patients on dialysis three times weekly with good performance status, ages 62 to 78, two with exon 19 deletion-positive disease and one with exon 21 mutation-positive disease. All patients were given reduced-dose afatinib at $30 \mathrm{mg}$ daily and observed partial responses in their dis- 
ease without significant side effects. Most notably, PK analyses based on blood samples taken on days before and after dialysis were similar to those in patients with normal organ function (Boehringer Ingelheim, 2016; Imai et al., 2016).

Osimertinib: The third-generation EGFR inhibitor and only treatment for T790M mutationpositive disease, osimertinib (Tagrisso), has no available literature available through PubMed or from the manufacturer with regards to dosing and experience in patients undergoing dialysis (AstraZeneca, 2015).

Alectinib: Of the available ALK inhibitors, alectinib (Alecensa) was the only agent to have any literature on use in a patient on dialysis. In the dose-finding portion of the phase $1 / 2$ AF-002JG study, a patient taking dose-reduced alectinib at $460 \mathrm{mg}$ twice daily developed grade 4 acute renal failure secondary to a family history of hyperoxaluria associated with kidney stones. Therapy was withheld during workup and the patient started dialysis. After 60 days off treatment, the patient resumed alectinib at the same reduced dose. The patient remained on alectinib for more than 1.5 years, despite continued dependence on HD (Gadgeel et al., 2014; Genentech, 2015).

Crizotinib, Brigatinib, and Ceritinib: The other available ALK inhibitor therapies, crizotinib (Xalkori), brigatinib (Alunbrig), and ceritinib (Zykadia), have no available literature available through PubMed or from the manufacturer with regards to dosing and experience in patients undergoing dialysis (Novartis, 2016; Pfizer, 2016b; Takeda, 2017).

\section{Immunotherapy}

Immunotherapy has revolutionized the cancer treatment paradigm by harnessing the patient's own immune system to target evading cancer cells (Table 7). The first US Food and Drug Administration approvals for non-small cell lung cancer within this category were nivolumab (Opdivo) and pembrolizumab (Keytruda), based on response rates and durable overall survival data.

Nivolumab: Nivolumab is a fully human immunoglobulin G4 (IgG4) mAb that selectively inhibits programmed cell death protein 1 (PD-1) activity by binding to the PD-1 receptor to block the ligands PD-L1 and PD-L2 (Bristol-Myers Squibb, 2017).
The negative $\mathrm{PD}-1$ receptor signaling that regulates T-cell activation and proliferation is disrupted, resulting in the inhibition of the immune response, including the antitumor immune response (Robert, 2015). There is no information from the manufacturer with regards to PK studies or experience in patients on dialysis (Table 8). However, there have been case reports that have shown nivolumab can be safely administered to ESRD patients. A 77-yearold male with metastatic clear cell renal cell carcinoma received fourth-line nivolumab while on dialysis; however, the timing of the dialysis in relation to the administration of nivolumab was not mentioned in the case report. The patient received 8 doses of nivolumab and showed significant disease improvement (Carlo \& Feldman, 2016).

Pembrolizumab: Pembrolizumb is a selective humanized IgG4 $-\kappa \mathrm{mAb}$ that inhibits the PD-1 receptor, which plays a pivotal role in immune checkpoint regulation in the tumor microenvironment (Dang, Ogunniyi, Barbee, \& Drilon, 2016). Blocking the PD-1 pathway inhibits the negative immune regulation caused by $\mathrm{PD}-1$ receptor signaling (Hamid, 2013). There is no information from the manufacturer with regards to PK studies or experience in patients on dialysis (Merck, 2016). However, there have been case reports that have shown pembrolizumab can be safely administered to ESRD patients. A 63-year-old male with metastatic melanoma was treated with pembrolizumab while on dialysis. The patient received dialysis three times a week and completed 10 cycles of pembrolizumab, and last reported with a complete remission. Due to the size of the antibodies, the authors suggested that pembrolizumab can be given without regard to the timing of dialysis (Chang \& Shirai, 2016).

Atezolizumab: Atezolizumab (Tecentriq) is a humanized $\mathrm{mAb}$ immune checkpoint inhibitor that binds to PD-L1 to selectively prevent the interaction between $\mathrm{PD}-1$ and B7-1 (CD80) receptors (Fehrenbacher et al., 2016). There is no available literature through PubMed or from the manufacturer with regards to dosing and experience in patients undergoing dialysis (Genentech, 2016b).

\section{CONCLUSION}

In summary, many drugs used in the treatment of lung cancer may be safely administered to patients 
Table 7. Immunotherapy for Lung Cancer

\begin{tabular}{|c|c|c|c|c|}
\hline Medication & Indication & Dose & Metabolism/elimination & Molecular weight \\
\hline Atezolizumab & $\begin{array}{l}\text { Patients with metastatic NSCLC } \\
\text { who have disease progression } \\
\text { during or following platinum- } \\
\text { containing chemotherapy } \\
\text { - Patients with EGFR or ALK } \\
\text { genomic tumor aberrations should } \\
\text { have disease progression on } \\
\text { FDA-approved therapy for these } \\
\text { aberrations prior to receiving } \\
\text { atezolizumab }\end{array}$ & $\begin{array}{l}1,200 \mathrm{mg} \text { once } \\
\text { every } 3 \text { weeks }\end{array}$ & $\begin{array}{l}\text { T-cell mediated } \\
\text { elimination; half-life is } \\
27 \text { days }\end{array}$ & $145 \mathrm{kDa}$ \\
\hline Nivolumab & $\begin{array}{l}\text { - Treatment for metastatic NSCLC } \\
\text { and progression on or after } \\
\text { platinum-based chemotherapy } \\
\text { - Patients with EGFR or ALK } \\
\text { genomic tumor aberrations should } \\
\text { have disease progression on } \\
\text { FDA-approved therapy for these } \\
\text { aberrations prior to receiving } \\
\text { nivolumab }\end{array}$ & $\begin{array}{l}240 \text { mg once } \\
\text { every } 2 \text { weeks }\end{array}$ & N/A; half-life is 27 days & $146 \mathrm{kDa}$ \\
\hline Pembrolizumab & $\begin{array}{l}\text { - Treatment for metastatic NSCLC } \\
\text { with high PD-L1 expression (TPS } \\
\geq 50 \% \text { ) with no EGFR or } A L K \\
\text { genomic tumor aberrations, and } \\
\text { no prior systemic chemotherapy } \\
\text { treatment } \\
\text { - Treatment for metastatic NSCLC } \\
\text { with PD-L1 expression (TPS } \geq 1 \% \text { ) } \\
\text { with disease progression on or after } \\
\text { platinum-containing chemotherapy } \\
\text { - Patients with EGFR or ALK } \\
\text { genomic tumor aberrations should } \\
\text { have disease progression on } \\
\text { FDA-approved therapy for these } \\
\text { aberrations prior to receiving } \\
\text { pembrolizumab }\end{array}$ & $\begin{array}{l}200 \text { mg once } \\
\text { every } 3 \text { weeks }\end{array}$ & $\begin{array}{l}\text { Phagocytosis by cells of } \\
\text { the reticuloendothelial } \\
\text { system into fragment } \\
\text { and then renally } \\
\text { eliminated; half-life is } \\
26 \text { days }\end{array}$ & 149 kDa \\
\hline
\end{tabular}

who are undergoing HD. Although these patients may have several comorbid conditions and multiple medications to manage, they can still be offered treatment for lung cancer. Dose adjustments and the timing of HD in regards to the administration of chemotherapy, immunotherapy, and targeted agents must be taken into consideration. There is a paucity of data and case studies with targeted agents and immunotherapy. It is imperative for clinicians to document and add to the body of evidence on the use of these agents in patients receiving HD. Clinicians must follow package inserts and clinical experiences in the management of these patients to mitigate serious complications.

\section{Table 8. Renal Dose Adjustments for Immunotherapy for Lung Cancer per Package Inserts}

\begin{tabular}{|c|c|c|c|c|}
\hline Medication & Mild impairment & Moderate impairment ${ }^{a}$ & Severe impairment ${ }^{b}$ & Dialysis \\
\hline Atezolizumab & $\mathrm{N} / \mathrm{A}$ & $\mathrm{N} / \mathrm{A}$ & N/A & $\mathrm{N} / \mathrm{A}$ \\
\hline Nivolumab & N/A & N/A & N/A & N/A \\
\hline Pembrolizumab & $\mathrm{N} / \mathrm{A}$ & N/A & N/A & $\mathrm{N} / \mathrm{A}$ \\
\hline
\end{tabular}




\section{Disclosure}

Ms. Eaby-Sandy has served in a consultant role for AbbVie and Ariad/Takeda, and has served on speakers bureaus for Amgen, AstraZeneca, Helsinn, and Merck. Dr. Leung, Dr. Hughes, Dr. Cambareri, and Dr. Rubin have no conflicts of interest to disclose.

\section{References}

Ashizawa, T., Iwahori, T., Yokoyama, T., Kihara, Y., Konno, O., Jyojima, Y.,...Nagao T. (2010). Irinotecan hydrochloride (CPT-11) in dialysis patients with gastrointestinal cancer. Acta Medica Okayama, 64(1), 19-26. Retrieved from https://www.ncbi.nlm.nih.gov/pubmed/20200580

AstraZeneca. (2015). Tagrisso (osimertinib) package insert. Retrieved from http://www.azpicentral.com/tagrisso/ tagrisso.pdf \#page $=1$

Baur, M., Fazeny-Doerner, B., Olsen, S. J., \& Dittrich, C. (2008). High dose single-agent paclitaxel in a hemodialysis patient with advanced ovarian cancer: A case report with pharmacokinetic analysis and review of the literature. International Journal of Gynecological Cancer, 18(3), 564570. https://doi.org/10.1111/j.1525-1438.2007.01048.x

Bersanelli, M., Tiseo, M., Artioli, F., Lucchi, L., \& Ardizzoni, A. (2014). Gefitinib and afatinib treatment in an advanced nonsmall cell lung cancer (NSCLC) patient undergoing hemodialysis. Anticancer Research, 34(6), 3185-3188. Retrieved from https://www.ncbi.nlm.nih.gov/pubmed/24922692

Boehringer Ingelheim. (2016). Gilotrif (afatinib) package insert. Retrieved from http://docs.boehringer-ingelheim. com/Prescribing\%20Information/PIs/Gilotrif/Gilotrif. pdf?DMW_FORMAT $=$ pdf

Brandes, J. C., Grossman, S. A., \& Ahmad, H. (2006). Alteration of pemetrexed excretion in the presence of acute renal failure and effusions: presentations of a case and review of the literature. Cancer Investigation, 24(3), 283-287. https://doi.org/10.1080/07357900600629567

Bristol-Myers Squibb. (2010b). Paraplatin (carboplatin) package insert. Retrieved from http://packageinserts.bms. com/pi/pi_paraplatin.pdf

Bristol-Myers Squibb. (2010a). Platinol (cisplatin) package insert. Retrieved from http://www.accessdata.fda.gov/drugsatfda_docs/label/2011/018057s080lbl.pdf

Bristol-Myers Squibb. (2011). Taxol (paclitaxel) package insert. Retrieved from http://packageinserts.bms.com/pi/ pi_taxol.pdf

Bristol-Myers Squibb. (2016). Etopophos (etoposide phosphate) package insert. Retrieved from http://packageinserts.bms.com/pi/pi_etopophos.pdf

Bristol-Myers Squibb. (2017). Opdivo (nivolumab) package insert. Retrieved from http://packageinserts.bms.com/pi/ pi_opdivo.pdf

Calvert, A., Newell, D., Gumbrell, L., O'Reilly, S., Burnell, M., Boxall, F.,...Wiltshaw, E. (1989). Carboplatin dosage: Prospective evaluation of a simple formula based on renal function. Journal of Clinical Oncology, 7(11), 1748-1756. https://doi.org/10.1200/JCO.1989.7.11.1748

Carlo, M. I., \& Feldman, D. R. (2016). Response to nivolumab in a patient with metastatic clear cell renal cell carcinoma and end-stage renal disease on dialysis. European Urology, 70(6), 1082-1085. https://doi.org/10.1016/j.eururo.2016.05.040

Celgene. (2015). Abraxane (albumin-bound) package insert.
Retrieved from http://abraxane.com/downloads/Abraxane_PrescribingInformation.pdf

Chang, R., \& Shirai, K. (2016). Safety and efficacy of pembrolizumab in a patient with advanced melanoma on haemodialysis. BMJ Case Reports. https://doi.org/10.1136/bcr2016-216426

Charlier, C., Kintz, P., Dubois, N., \& Plomteux, G. (2004). Fatal overdosage with cisplatin. Journal of Analytical Toxicology, 28(2), 138-140. https://doi.org/10.1093/jat/28.2.138

Czock, D., Rasche, F. M., Boesler, B., Shipkova, M., \& Keller, F. (2009). Irinotecan in cancer patients with end-stage renal failure. Annals of Pharmacotherapy, 43(2), 363-369. https://doi.org/10.1345/aph.1L511

Dang, T. O., Ogunniyi, A., Barbee, M. S., \& Drilon, A. (2016). Pembrolizumab for the treatment of PD-L1 positive advanced or metastatic non-small cell lung cancer. Expert Review of Anticancer Therapy, 16(1), 13-20. https://doi.org $/ 10.1586 / 14737140.2016 .1123626$

Del Conte, A., Minatel, E., Schinella, D., Baresic, T., \& Basso, S. M., \& Lumachi, F. (2014). Complete metabolic remission with gefitinib in a hemodialysis patient with bone metastases from non-small cell lung cancer. Anticancer Research, 34(1), 319-322. Retrieved from https://www.ncbi. nlm.nih.gov/pubmed/24403481

Eli Lilly. (2013). Alimta (pemetrexed) package insert. Retrieved from http://pi.lilly.com/us/alimta-pi.pdf

Eli Lilly. (2014). Gemzar (gemcitabine) package insert. Retrieved from http://pi.lilly.com/us/gemzar.pdf

Eli Lilly. (2015). Portrazza (necitumumab) package insert. Retrieved from http://uspl.lilly.com/portrazza/portrazza. html\#pi

Eli Lilly. (2017). Cyramza (ramucirumab) package insert. Retrieved from http://uspl.lilly.com/cyramza/cyramza.html

Evaluation of Genomic Applications in Practice and Prevention Working Group. (2009). Recommendations from the EGAPP Working Group: Can UGT1Al genotyping reduce morbidity and mortality in patients with metastatic colorectal cancer treated with irinotecan? Genetics in Medicine, 11(1), 15-20. https://doi.org/10.1097/ GIM.0b013e31818efd9d

Fehrenbacher, L., Spira, A., Ballinger, M., Kowanetz, M., Vansteenkiste, J., Mazieres, J., \& Rittmeyer, A. (2016). Atezolizumab versus docetaxel for patients with previously treated non-small-cell lung cancer (POPLAR): A multicenter, open-label, phase 2 randomised controlled trial. Lancet, 387(10030), 1837-1846. https://doi.org/10.1016/ S0140-6736(16)00587-0

Fong, M. K., Fetterly, G. J., Jr., McDougald, L. J., \& Iyer, R. V. (2014). Carboplatin pharmacokinetics in a patient receiving hemodialysis. Pharmacotherapy, 34(2), e9-e13. https:// doi.org/10.1002/phar.1354

Fuchs, C. S., Tomasek, J., Yong, C. J., Dumitru, F., Passalacqua, R., Goswami, C.,...Tabernero, J. (2014). Ramucirumab monotherapy for previously treated advanced gastric or gastro-oesophageal junction adenocarcinoma (REGARD): An international, randomized, multicenter, placebo-controlled, phase 3 trial. Lancet, 383(9911), 31-39. https://doi. org/10.1016/S0140-6736(13)61719-5

Fujita, K., Sunakawa, U., Miwa, K., Akiyama, Y., Sugiyama, M., \& Kawara, K.,...Sasaki, Y. (2011). Delayed elimination of $\mathrm{SN}-38$ in cancer patients with severe renal failure. Drug Metabolism and Disposition, 39(2), 161-164. https://doi. org/10.1124/dmd.110.035451 
Gadgeel, S. M., Gandhi, L., Riely, G. J., Chiappori, A. A., West, H. L., Azada, M. C.,...Ou, S. H. (2014). Safety and activity of alectinib against systemic disease and brain metastases in patients with crizotinib-resistant ALK-rearranged nonsmall-cell lung cancer (AF-002JG): Results from the dosefinding portion of a phase 1/2 study. Lancet Oncology, 15(10), 1119-1128. https://doi.org/10.1016/S1470-2045(14)70362-6

Garnier-Viougeat, N., Rixe, O., Paintaud, G., Ternant, D., Degenne, D., Mouawad, R.,...Izzedine, H. (2007). Pharmacokinetics of bevacizumab in haemodialysis. Nephrology Dialysis Transplantation, 22(3), 975. https://doi.org/10.1093/ ndt/gfl664

Genentech. (2015). Alecensa (alectinib) package insert. Retrieved from https://www.gene.com/download/pdf/alecensa_prescribing.pdf

Genentech. (2016a). Avastin (bevacizumab) package insert. Retrieved from https:/www.gene.com/download/pdf/ avastin_prescribing.pdf

Genentech. (2016b). Tecentriq (atezolizumab) package insert. Retrieved from https://www.gene.com/download/pdf/tecentriq_prescribing.pdf

Genentech/Astellas Oncology. (2016). Tarceva (erlotinib) package insert. Retrieved from https://www.gene.com/ download/pdf/tarceva_prescribing.pdf

Glassman, P. M., \& Balthasar, J. P. (2014). Mechanistic considerations for the use of monoclonal antibodies for cancer therapy. Cancer Biology and Medicine, 11(1), 20-33. https:// doi.org/10.7497/j.issn.2095-3941.2014.01.002

GlaxoSmithKline. (2002). Navelbine (vinorelbine tartrate) package insert. Retrieved from https://www.accessdata. fda.gov/drugsatfda_docs/label/2014/020388s027lbl.pdf

Hamid, O., Robert, C., Daud, A., Hodi, F. S., Hwu, W. J., Kefford, R.,...Ribas, A. (2013). Safety and tumor responses with lambrolizumab (anti-PD-1) in melanoma. New England Journal of Medicine, 369(2), 134-144. https://doi. org/10.1056/NEJMoal305133

Herrington, J. D., Figueroa, J. A., Kirstein, M. N., Zamboni, W. C., \& Stewart, C. F. (2001). Effect of hemodialysis on topotecan disposition in a patient with severe renal dysfunction. Cancer Chemotherapy and Pharmacology, 47(1), 89-93. https://doi.org/10.1007/s002800000224

Hochegger, K., Lhotta, K., Mayer, G., Czejka, M., \& Hilbe, W. (2007). Pharmacokinetic analysis of docetaxel during haemodialysis in a patient with locally advanced nonsmall cell lung cancer. Nephrology Dialysis Transplantation, 22(1), 289-290. https://doi.org/10.1093/ndt/gfl498

Ide, H., Satou, A., Hoshino, K., Yasumizu, Y., Uchida, Y., Tasaka, Y.,...Masuda T. (2011). Successful management of metastatic urothelial carcinoma with gemcitabine and paclitaxel chemotherapy in a hemodialysis patient. Urology Internationalis, 87(2), 245-247. https://doi.org/10.1159/000327511

Imai, H., Kaira, K., Naruse, I., Hayashi, H., Iihara, H., Kita, Y.,... Yamada, M. (2016). Successful afatinib treatment of advanced non-small-cell lung cancer patients undergoing hemodialysis. Cancer Chemotherapy and Pharmacology, 79(1), 209-213. https://doi.org/10.1007/s00280-016-3201-9

Inauen, R., Cathomas, R., Boehm, T., Koeberle, D., Pestalozzi, B. C., Gillessen, S., \& von Moos, R. (2007). Feasibility of using cetuximab and bevacizumab in a patient with colorectal cancer and terminal renal failure. Oncology, 72(3-4), 209210. https://doi.org/10.1159/000112828

Inoue, A., Saijo, Y., Kikuchi, T., Gomi, K., Suzuki, T., Maemondo, M.,...Nukiwa, T. (2004). Pharmacokinetic analysis of com- bination chemotherapy with carboplatin and etoposide in small-cell lung cancer patients undergoing hemodialysis. Annals of Oncology, 15(1), 51-54. https://doi.org/10.1093/ annonc/mdh008

Janus, N., Launay-Vacher, V., Thyss, A., Boulanger, H., Moranne, O., Islam, M. S.,...Thariat J. (2013). Management of anticancer treatment in patients under chronic dialysis: Results of the multicentric CANDY (CANcer and DialYsis) study. Annals of Oncology, 24(2), 501-507. https://doi. org/10.1093/annonc/mds344

Janus, N., Thariat, J., Boulanger, H., Deray, G., \& Launay-Vacher, V. (2010). Proposal for dosage adjustment and timing of chemotherapy in hemodialyzed patients. Annals of Oncology, 21(7), 1395-1403. https://doi.org/10.1093/annonc/ mdp598

Jen, J. F., Cutler, D. L., Pai, S. M., Batra, V. K., Affrime, M. B., Zambas, D. N.,...Hajian, G. (2000). Population pharmacokinetics of temozolomide in cancer patients. Pharmaceutical Research, 17(10), 1284-1289. https://doi. org/10.1023/A:1026403805756

Kaneda, H., Okamoto, I., \& Nakagawa, K. (2012). Pharmacokinetics of docetaxel in patient with non-small cell lung cancer undergoing continuous ambulatory peritoneal dialysis. Journal of Thoracic Oncology, 7(3), 621-622. https:// doi.org/10.1097/JTO.0b013e3182460f67

Kiani, A., Kohne, C., Franz, T., Passauer, J., Haufe, T., Gross, P.,... Schleyer, E. (2003). Pharmacokinetics of gemcitabine in a patient with end-stage renal disease: Effective clearance of its main metabolite by standard hemodialysis treatment. Cancer Chemotherapy and Pharmacology, 51(3), 266-270. Retrieved from https://www.ncbi.nlm.nih.gov/ pubmed/12655447

Kim, D. M., Kim, H. L., Chung, C. H., \& Park, C. Y. (2009). Successful treatment of small-cell lung cancer with irinotecan in a hemodialysis patient with end-stage renal disease. Korean Journal of Internal Medicine, 24(1), 73-75. https:// doi.org/10.3904/kjim.2009.24.1.73

Kodama, J., Sasaki, A., Masahiro, S., Seki, N., Kusumoto, T., Nakamura, K.,...Hiramatsu, Y. (2010). Pharmacokinetics of combination chemotherapy with paclitaxel and carboplatin in a patient with advanced epithelial ovarian cancer undergoing hemodialysis. Oncology Letters, 1(3), 511-513. https://doi.org/10.3892/ol_00000090

Masumori, N., Kunishima, Y., Hirobe, M., Takeuchi, M., Takayanagi, A., Tsukamoto, T., \& Itoh, T. (2008). Measurement of plasma concentration of gemcitabine and its metabolite $\mathrm{dFdU}$ in hemodialysis patients with advanced urothelial cancer. Japanese Journal of Clinical Oncology, 38(3), 182185. https://doi.org/10.1093/jjco/hyml71

Merck. (2008). Temodar (temozolomide) package insert. Retrieved from https://www.merck.com/product/usa/pi circulars/t/temodar_capsules/temodar_pi.pdf

Merck. (2016). Keytruda (pembrolizumab) package insert. Retrieved from http://www.merck.com/product/usa/ pi_circulars/k/keytruda/keytruda_pi.pdf

Novartis. (2015). Hycamtin (topotecan) package insert. Retrieved from https://www.pharma.us.novartis.com/sites/ www.pharma.us.novartis.com/files/hycamtin_inj.pdf

Novartis. (2016). Zykadia (ceritinib) package insert. Retrieved from https://www.pharma.us.novartis.com/sites/www. pharma.us.novartis.com/files/zykadia.pdf

O’Reilly, S., Rowinsky, E. K., Slichenmyer, W, Donehower, R. C., Forastiere, A. A., Ettinger, D. S.,...Grochow, L. B. (1996). 
Phase I and pharmacologic study of topotecan in patients with impaired with impaired renal function. Journal of Clinical Oncology, 14(12), 3062-3073. https://doi. org/10.1200/JCO.1996.14.12.3062

Oguri, T., Shimokata, T., Inada, M., Ito, I., Ando, Y., Sasaki, Y., \& Hasegawa., Y. (2010). Pharmacokinetic analysis of carboplatin in patients with cancer who are undergoing hemodialysis. Cancer Chemotherapy and Pharmacology, 66(4), 813-817. https://doi.org/10.1007/s00280-010-1366-1

Ohana, Z., Brahim, A., \& Ibrahim, M. (2016). Adjusted dosing and schedule of pemetrexed in impaired renal function. Journal of Hematology Oncology Pharmacy, 6(3), 103-107.

Panoilia, E., Schindler, E., Samantas, E., Aravantinos, G., Kalofonos, H. P., Christodoulou, C.,...Sivolapenko, G. (2015). A pharmacokinetic binding model for bevacizumab and VEGF165 in colorectal cancer patients. Cancer Chemotherapy and Pharmacology, 75(4), 791-803. https://doi. org/10.1007/s00280-015-2701-3

Pfizer. (2016a). Camptosar (irinotecan hydrochloride injection) package insert. Retrieved from http://labeling.pfizer. com/ShowLabeling.aspx?id=533

Pfizer. (2016b). Xalkori (crizotinib) package insert. Retrieved from http://labeling.pfizer.com/showlabeling. aspx? $\mathrm{id}=676$

Robert, C., Long, G. V., Brady, B., Dutriaux, C., Maio, M., Mortier, L.,...Ascierto, P. A. (2015). Nivolumab in previously untreated melanoma without BRAF mutation. New England Journal of Medicine, 372, 320-330. https://doi.org/10.1056/ NEJMoal412082

Rombola, G., Vaira, F., Trezzi, M., Chiappini, N., Falgui, V., \& Londrino, F. (2015). Pemetrexed induced acute kidney injury in patients with non-small cell lung cancer: Reversible and chronic renal damage. Journal of Nephrology, 28(2), 187-91. https://doi.org/10.1007/s40620-014-0117-5

Sahni, V., Choudhury, D., \& Ahmed, Z. (2009). Chemotherapyassociated renal dysfunction. Nature Reviews Nephrology, 5(8), 450-462. https://doi.org/10.1038/nrneph.2009.97

Sanofi-Aventis. (2015). Taxotere (docetaxel) package insert. Retrieved from http://products.sanofi.us/Taxotere/taxotere.html

Shinagawa, N., Yamazaki, K., Asahina, H., Agata, J., Itoh, T., \& Nishimura, M. (2007). Gefitinib administration in a patient with lung cancer undergoing hemodialysis. Lung Cancer, 58(3), 422-424. https://doi.org/10.1016/j.lungcan.2007.06.001

Siefker-Radtke, A. O., Campbell, M. T., Munsell, M. F., Harris, D. R., Carolla, R. L., \& Pagliaro, L. C. (2016). Front-line treatment with gemcitabine, paclitaxel, and doxorubicin for patients with unresectable or metastatic urothelial cancer and poor renal function: Final results from a phase II study. Urology, 89, 83-89. https://doi.org/10.1016/j.urology.2015.12.007

Spratlin, J. L., Cohen, R. B., Eadens, M., Gore, L., Camidge, D. R., Diab, S.,...Eckhardt, S. G. (2010). Phase I pharmacologic and biologic study of ramucirumab (IMC-1121B), a fully human immunoglobulin G1 monoclonal antibody targeting the vascular endothelial growth factor receptor-2. Journal of Clinical Oncology, 28(5), 780-787. https://doi. org/10.1200/JCO.2009.23.7537

Takakura, K., Koido, S., Takahara, A., Odahara, S., Mitobe, J., Matsudaira, H.,...Tajiri H. (2014). Long-term management of gemcitabine in a patient with advanced pancreatic cancer undergoing haemodialysis. Journal of Chemotherapy, 26(6), 369-372. https://doi.org/10.1179/197394781
3Y.0000000150

Takeda. (2017). Alunbrig (brigatinib) package insert. Retrieved from https://www.accessdata.fda.gov/drugsatfda_docs/ label/2017/208772lbl.pdf

Takezawa, K., Okamoto, I., Fukuoka, M., \& Nakagawa, K. (2008). Pharmacokinetic analysis of carboplatin and etoposide in a small cell lung cancer patient undergoing hemodialysis. Thoracic Oncology, 3(9), 1073-1075. https:// doi.org/10.1097/JTO.0b013e318183af89

Tanaka, S. (2015). Carboplatin and weekly paclitaxel chemotherapy in hemodialysis patient with advanced lung cancer and severe comorbidity: Effect of the drugs and their chemical intermediates. Research on Chemical Intermediates, 41(9), 6825-6832. https://doi.org/10.1007/s11164-014-1780-9

Thatcher, N., Hirsch, F. R., Luft, A. V., Szczesna, A., Ciuleanu, T. E., Dediu, M.,...Socinski, M. A. (2015). Necitumumab plus gemcitabine and cisplatin versus gemcitabine and cisplatin alone as first-line therapy in patients with stage IV squamous non-small-cell lung cancer (SQUIRE): An open-label, randomized, controlled phase 3 trials. Lancet Oncology, 16(7), 763-774. https://doi.org/10.1016/S1470-2045(15)00021-2

Togashi, Y., Kim, Y. H., Masago, K., Sakamori, Y., Okuda, C., Mio, T., \& Mishima, M. (2011). Long-term survival in a patient with small-cell lung cancer undergoing hemodialysis who received multiple courses of chemotherapy. Japanese Journal of Clinical Oncology, 41(4), 582-585. https://doi. org/10.1093/jjco/hyq244

Tomita, M., Kurata, H., Aoki, Y., Tanaka, K., \& Kazama, J. (2001). Pharmacokinetics of paclitaxel and cisplatin in a hemodialysis patient with recurrent ovarian cancer. Anti-Cancer Drugs, 12(5), 485-487. https://doi.org/10.1097/00001813200106000-00010

Togashi, Y., Masago, K., Fukudo, M., Terada, T., Ikemi, Y., Kim, Y. H.,...Mishima, M. (2010). Pharmacokinetics of erlotinib and its active metabolite OSI-420 in patients with nonsmall cell lung cancer and chronic renal failure who are undergoing hemodialysis. Journal of Thoracic Oncology, 5(5), 601-605. https://doi.org/10.1097/JTO.0b013e3181d32287

Watanabe, M., Aoki, Y., Tomita, M., Sato, T., Takaki, Y., Kato, N.,...Tanaka, K. (2002). Paclitaxel and carboplatin combination chemotherapy in a hemodialysis patient with advanced ovarian cancer. Gynecologic Oncology, 84(2), 335338. https://doi.org/10.1006/gyno.2001.6527

Watanabe, R., Takiguchi, Y., Moriya, T., Oda, S., Kurosu, K., Tanabe, N.,...Kuriyama, T. (2003). Feasibility of combination chemotherapy with cisplatin and etoposide for haemodialysis patient with lung cancer. British Journal of Cancer, 88, 25-30. https://doi.org/10.1038/sj.bjc.6600687

Yamaguchi, T., Isogai, S., \& Okamura, T. (2015). Pharmacokinetics of gefitinib in a patient with non-small cell lung cancer undergoing continuous ambulatory peritoneal dialysis. Case Reports in Oncology, 8(1), 78-82. https://doi. org/10.1159/000375485

Yang, L., Zhang, X.-C., Yu, S.-F., Zhu, H.-Q., Hu, A.-P., Chen, J., \& Shen, P. (2015). Pharmacokinetics and safety of cyclophosphamide and docetaxel in a hemodialysis patient with early stage breast cancer: A case report. BMC Cancer, 15, 917-921. https://doi.org/10.1186/s12885-015-1932-3

Yoshida, H., Sumi, T., Abe, K., \& Ishiko, O. (2009). Pharmacokinetics of paclitaxel and carboplatin in a hemodialysis patient with advanced ovarian cancer. European Journal of Gynaecology and Oncology, 30(5), 583-585. Retrieved from https://www.ncbi.nlm.nih.gov/pubmed/19899423 